\title{
ERRATUM
}

\section{Uncertified Facility (BSL 2 plus): Its Journey through Life for Preparations and Setting up, Compliance with Biosafety Regulations, Implementation, and Registration of the Facility with the Ministry of Health, Singapore}

Tin Tun, Xander Sim

Department of Research \& Development, Cell ID Private Company Limited, Singapore, Singapore

https://doi.org/10.15324/kjcls.2021.53.1.68

The following Erratum are to address inaccurate statements in the paper which could mislead readers and to clarify the BATA's requirements.

The corrections have been made in PDF manuscript.

\begin{tabular}{|c|c|c|}
\hline Position in the paper & Original wording & To replace with \\
\hline $\begin{array}{l}\text { Page: 69; Section: Introduction; } \\
\text { Part 1: The BATA; Table 1; } \\
\text { Schedule } 1 \text { (Part II); Column } 3\end{array}$ & $\begin{array}{c}\text { “(Uncertified facility and } \\
\text { protected place can appeal)" }\end{array}$ & $\begin{array}{l}\text { "(Appeal for an approval to possess Schedule } 1 \\
\text { Part II biological agents in a facility not designated as } \\
\text { a Protected Place is not allowed. However, in light of } \\
\text { the COVID-19 pandemic situation, a general exemption } \\
\text { was granted for SARS-CoV-2 through a government } \\
\text { gazetted Subsidiary Legislation.)" }\end{array}$ \\
\hline $\begin{array}{l}\text { Page: 69; Section: Introduction; } \\
\text { Part 1: The BATA; Table 1; } \\
\text { Schedule 2; Column } 3\end{array}$ & $\begin{array}{l}\text { "Certified BSL3 and protected place } \\
\text { with special approval granted by the director } \\
\text { (medical services)" }\end{array}$ & $\begin{array}{l}\text { "Certified BSL4 and protected place with } \\
\text { special approval granted by the Director } \\
\text { (Medical services)" }\end{array}$ \\
\hline $\begin{array}{l}\text { Page: 69; Section: Introduction; } \\
\text { Part 1: The BATA; Table 1; } \\
\text { Schedule 3; Column } 2\end{array}$ & $\begin{array}{c}\text { "Can cause serious human or animal disease } \\
\text { but unlikely } \\
\text { to be a serious hazard" }\end{array}$ & $\begin{array}{l}\text { "Can cause human or animal disease but unlikely } \\
\text { to be a serious hazard to laboratory workers, the } \\
\text { community or the environment" }\end{array}$ \\
\hline $\begin{array}{l}\text { Page: 69; Section: Introduction; } \\
\text { Part 1: The BATA; Table 1; } \\
\text { Schedule 4; Column } 2\end{array}$ & "Low or no individual and community risk" & "Low individual and community risk" \\
\hline $\begin{array}{l}\text { Page: 69; Section: Introduction; } \\
\text { Part 1: The BATA; Table 1; } \\
\text { Schedule 4; Column } 3\end{array}$ & $\begin{array}{l}\text { "Conditions of the permit granted } \\
\text { by the director (medical services)" }\end{array}$ & (Not applicable, to be deleted) \\
\hline $\begin{array}{l}\text { Page: 69; Section: Introduction; } \\
\text { Part 1: The BATA; Table 1; } \\
\text { Schedule 5; Column } 3\end{array}$ & "Protected palace" & "Protected place" \\
\hline $\begin{array}{l}\text { Page: 70; Section: Introduction; } \\
\text { Part 2: Legislation requirements, } \\
\text { guidelines and circulars; } \\
\text { Paragraph } 1\end{array}$ & $\begin{array}{l}\text { "However the } \mathrm{MOH} \text { issues the interim } \\
\text { biosafety guidelines for research } \\
\text { laboratories and diagnostic laboratories } \\
\text { and personnel handling samples or } \\
\text { materials associated with the inactivated } \\
\text { schedule } 1 \text { biological agents." }\end{array}$ & $\begin{array}{l}\text { "MOH may issue Interim guidelines for research } \\
\text { laboratories and diagnostic laboratories, especially in the } \\
\text { event of an emerging infectious disease with uncertain } \\
\text { risk profile. An interim guideline was issued for } \\
\text { SARS-CoV-2, and in the past, for MERS-CoV and H1N1 } \\
\text { virus when they were first emerged. }\end{array}$ \\
\hline
\end{tabular}

Corresponding author: Tin Tun

Department of Research \& Development, Cell ID Private Company Limited, 3 Gambas Crescent, Nordcom One, \#09-02/03/04/05/07/08/09, Singapore 757088, Singapore E-mail: tintun64@gmail.com

ORCID: https://orcid.org/0000-0002-7841-7645 


\begin{tabular}{l} 
Position in the paper \\
\hline Page: 70; Section: Introduction; \\
Part 2: Legislation requirements, \\
guidelines and circulars; \\
Paragraph 3 \\
Page: 70; Section: Introduction; \\
Part 2: Legislation requirements, \\
guidelines and circulars; \\
Paragraph 3 \\
Page: 72; Section: Introduction; \\
Part 2: Legislation requirements, \\
guidelines and circulars; \\
Table 2: Title \\
Page: 76; Section: Materials and \\
Methods; Part 10: Emergency \\
responses; Paragraph 2
\end{tabular}

Page: 76; Section: Results; Part 1: Appeal for exemption from the BATA; Paragraph 1

Page: 78; Section: Results; Part 4: Registration and approvals; Paragraph 2

Page: 79; Section: Results; Part 5: Documentation; Paragraph 2

Page: 79; Section: Discussion; Paragraph 1
Original wording

"Ensuring that appropriate biosafety procedures and practices are in place and that research activities are carried out in a safe manner, research facilities can make an appeal for exemption from BATA control for their non-diagnostic activities involving inactivated schedule 1 biological agents." "Having thorough reviews of the application the $\mathrm{MOH}$ will approve to handle inactivated First Schedule biological agents in a BSL2"

"Precautions and requirements regarding safe use of COVID-19 samples associated with SARS-CoV-2 virus extracted from the $\mathrm{MOH}$ Interim Guidelines (MOH Circular 17/2020)"

"In case of laboratory acquired infection (LAI) and that the scheduled biological agents were involved the $\mathrm{MOH}$ is reported within one week."

"Having organized all preparations, an appeal application for the possession and use of

First Schedule biological agents to be exempted from the BATA is submitted to the $\mathrm{MOH}$ Biosafety"

"Thus, to handle and possess a First or Fifth

Schedule biological agents or toxins is valid in our research laboratory,"

"All documents, records, the IBC meeting minutes, accident/incident reports, permits, approvals and inventory records which are related to the BATA First and Fifth schedule biological agents and toxins such as HIV1/2 or COVID-19 virus need to be retained for at least 3 years or as per required duration."

"On the other hand, the guilty offender shall be liable on conviction to a fine of up to one million Singapore dollars or to imprisonment

for a term which may extend to life imprisonment or to both [2]."
To replace with

"Ensuring that appropriate biosafety procedures and practices are in place and that research activities are carried out in a safe manner, research facilities can use truly inactivated Schedule biological agents."

To delete.

"Precautions and requirements regarding safe use of COVID-19 samples associated with SARS-CoV-2 virus for diagnostic purposes as extracted from the $\mathrm{MOH}$ Interim Guidelines (MOH Circular 17/2020)"

"Cases of laboratory acquired infection (LAI) involving scheduled biological agents shall be reported to $\mathrm{MOH}$ as soon as possible."

"Having organized all preparations, an appeal application for approval to possess a

First Schedule biological agent (HIV) in an uncertified facility was submitted to the $\mathrm{MOH}$ Biosafety Branch."

"Thus, research work involving HIV in our laboratory is limited to activities proposed in the application and the approval to possess granted."

"All documents, records, the IBC meeting minutes, accident/incident reports, permits, approvals and inventory records which are related to the

BATA First Scheduled Part I biological agent applicable in the approval granted to the laboratory must be retained for at least 5 years or 3 years after the facility is deregistered."

"On the other hand, offenders convicted under the BATA shall be liable to a fine of up to one million Singapore dollars or to imprisonment for a term which may extend to life imprisonment or both, depending on the type of offence committed [2]." 